\title{
LIST OF TABLES AND MAPS
}

\section{Tables}

Table 2.1 Racial Changes in the Neighborhoods of Fairmount, Spring Garden, and Philadelphia, 1950-2000

Table 2.2 Economic and Housing Changes in Fairmount and Spring Garden Neighborhoods Compared to City-Wide Changes, 1960-2000

Table 2.3 Changes in Educational Background of Fairmount and Spring Garden Residences Compared to the City of Philadelphia, 1970-2000

Table 3.1 Estimates of the Market Value of the Seasonal Contribution of Unpaid Volunteers at Fairmount Sports Association by Level of Support

Table 4.1 Dimensions of Coaching Styles and Placement of Twenty Coaches

Table A.1 Overview of Data Sources and Samples

\section{Maps}

Map 1 Fairmount/Spring Garden and Surrounding Areas 
